\title{
PRODUCTION PARAMETERS OF PHF COWS DEPENDING ON VARYING HOUSING CONDITIONS DURING LACTATION
}

\section{PARAMETRY PRODUKCYJNE KRÓW RASY PHF W ZALEŻNOŚCI OD WARUNKÓW UTRZYMANIA PODCZAS LAKTACJI}

\author{
${ }^{1}$ Department of Animal Genetics and Breeding, National Research Institute of Animal Production \\ Kraków, Poland \\ ${ }^{2}$ KR Kietrz Ltd., Kietrz, Poland
}

\begin{abstract}
Streszczenie. Celem pracy było zbadanie wpływu zmiennych warunków utrzymania na parametry produkcyjne krów polskich rasy holszytyńsko-fryzyjskiej. Zwierzęta, pochodzące z Zakładu Doświadczalnego Instytutu Zootechniki PIB w Chorzelowie, podzielono na 3 grupy różniące się warunkami utrzymania. Czynnikami różnicującymi były dostęp do wybiegów oraz powierzchnia przypadająca na jedno zwierzę. Na krowy oddziaływano także poprzez zmianę obsady oraz przegrupowywanie zwierząt. Wyniki wykazały, że krowy bez dostępu do wybiegu $\left(3,8 \mathrm{~m}^{2} \mathrm{na}^{2}\right.$ zwierzę) produkowały o $2 \mathrm{~kg}$ mleka mniej niż zwierzęta mające do dyspozycji 7,74 $\mathrm{m}^{2}$. Zwiększenie zagęszczenia z 3,8 $\mathrm{m}^{2}$ do 2,71 $\mathrm{m}^{2}$ na zwierzę skutkowało zmniejszeniem produkcji mleka o 8,9 kg. U krów korzystających z wybiegów, przy zmniejszeniu powierzchni przypadającej na jedno zwierzę z 7,74 $\mathrm{m}^{2}$ do 5,35 $\mathrm{m}^{2}$, spadek produkcji mlecznej wyniósł 7,46 kg. Dwukrotne zmiany powierzchni bytowej, w tym zwiększenie powierzchni (w kolejnej grupie) z 6,24 $\mathrm{m}^{2}$ do $17,6 \mathrm{~m}^{2}$ także skutkowało spadkiem wydajności mlecznej o $6 \mathrm{~kg}$. Spadki wydajności mlecznej wiązały się ze zwiększeniem zawartości suchej masy w litrze mleka. Na podstawie badań stwierdzono, że system utrzymania i gęstość obsady determinują poziom produkcji mlecznej. Zbyt częste zmiany gęstości obsady, jak również zmiany składu grup zwierząt wpływały negatywnie na wydajność mleczną.
\end{abstract}

Key words: physical activity, animal behavior, overstocking, housing system, milk production. Słowa kluczowe: aktywność fizyczna, behawior zwierząt, nadmierne zagęszczenie, system utrzymania, wydajność mleczna.

\section{INTRODUCTION}

Recent studies have clearly demonstrated that housing conditions have a significant effect on the milk yield of cows. Gnyp et al. (2006) found that cows housed in free-stall barns produce significantly more milk with a higher protein and fat content. This was confirmed by a later study by Czerniawska-Piątkowska et al. (2008). In a study with three groups of TMR-fed cows (with outdoor access, without outdoor access, pastured fed), Radkowska (2012) showed that at the beginning of the grazing period (May, June), daily milk yield was similar in all the groups. During the next months (July to September) milk production decreased, with a highest, statistically significant decrease observed for pastured cows. Among the groups housed in the free-stall system, higher milk yield was achieved by animals without outdoor access, but

Corresponding author - Adres do korespondencji: Piotr Wójcik, Department of Animal Genetics and Breeding, National Research Institute of Animal Production, Sarego 2, 31-047 Kraków, Poland, e-mail: piotr.wojcik@izoo.krakow.pl 
their milk had a lower percentage of solids, protein and fat. Research has shown that cows as social animals feel safe in groups, and regrouping disrupts the social hierarchy (Abramowicz et al. 2014). On the other hand, introduction of new animals to a group causes stress and adversely affects the milk yield (Kraszewski et al. 2007). Also overstocking can influence milk yields by disrupting feeding behaviour, which may also induce diseases (Reinholz-Trojan 2007). This includes mastitis, which causes a decrease in milk yield (Hunc et al. 2006). The aim of the study was to determine the effect of varying housing conditions on production parameters of Polish Holstein-Friesian cows.

\section{MATERIAL AND METHODS}

The study was conducted in 2015-2016 at the Experimental Station of the National Research Institute of Animal Production in Chorzelów and involved a group of Polish Holstein-Friesian (PHF) cows. Animals from experimental groups were kept in free-stall sections of the same dimensions. Daily milking was carried out in a herringbone milking parlour and the uniform feeding system was based on TMR. During the study period, experimental cows were assigned to three groups with at least 25 animals per group.

- group I - cows housed in a section without outdoor access and subjected to periodic overstocking -25 animals, $3.80 \mathrm{~m}^{2} /$ head;

- group II - cows housed in a section with outdoor access and subjected to periodic overstocking - 25 animals, $7.74 \mathrm{~m}^{2} /$ head;

- group III - cows housed in a section with outdoor access and intended for increasing the stocking density in groups I and II -31 animals, $3.80 \mathrm{~m}^{2} /$ head.

All animals were milk recorded by the Polish Federation of Cattle Breeders and Dairy Farmers for milk yield on test day, fat content, protein content, lactose content, and somatic cell count. These parameters were determined by the Federation's laboratory. In addition, all the experimental animals from groups I, II and III were monitored daily by Afilab milk analysis system fitted in the milking parlour. The system recorded milk yields, estimated fat, protein and lactose content, fat to protein ratio, FCM and ECM yields, milking time and milk conductivity per day and in different milking sessions. To this end, three milking sessions were set:

- session I - $16.30-4.00$,

- session II - $4.30-11.00$,

- session III - $11.30-16.00$.

In different study periods, the animals were regrouped according to the following scheme (Table 1).

Table 1. Changes in stocking density and floor space allowance in different study groups according to experimental period

Tabela 1. Zmiany obsady zwierząt i powierzchnia bytowa w poszczególnych grupach badawczych, w zależności od okresu doświadczalnego

\begin{tabular}{|c|c|c|c|c|c|c|}
\hline \multirow{3}{*}{$\begin{array}{c}\text { Study period } \\
\text { Okres badawczy }\end{array}$} & \multicolumn{6}{|c|}{ Study group - Grupy badawcze } \\
\hline & \multicolumn{2}{|c|}{ I } & \multicolumn{2}{|c|}{ II } & \multicolumn{2}{|c|}{ III } \\
\hline & $\begin{array}{l}\text { head } \\
\text { szt. }\end{array}$ & $\begin{array}{l}\mathrm{m}^{2} / \text { head } \\
\mathrm{m}^{2} / \mathrm{szt} .\end{array}$ & $\begin{array}{l}\text { head } \\
\text { szt. }\end{array}$ & $\begin{array}{c}\mathrm{m}^{2} / \text { head } \\
\mathrm{m}^{2} / \mathrm{szt} .\end{array}$ & $\begin{array}{c}\text { head } \\
\text { szt. }\end{array}$ & $\begin{array}{c}\mathrm{m}^{2} / \text { head } \\
\mathrm{m}^{2} / \mathrm{szt} .\end{array}$ \\
\hline $\begin{array}{l}\text { Comparison period } \\
\text { Okres porównawczy }\end{array}$ & 25 & 3.80 & 25 & 7.74 & 31 & 6.24 \\
\hline $\begin{array}{l}\text { Experimental period } 1 \\
\text { Okres doświadczalny } 1\end{array}$ & 30 & 3.16 & 30 & 6.45 & 21 & 9.21 \\
\hline $\begin{array}{l}\text { Experimental period } 2 \\
\text { Okres doświadczalny } 2\end{array}$ & 35 & 2.71 & 35 & 5.35 & 11 & 17.60 \\
\hline
\end{tabular}


The study determined the relationship between free and restricted access to the outdoors, as well as the relationship between normal and above-normal (overstocking) number of animals in a section and productive traits of the animals. The results were statistically analysed using SAS package and accounting for the studied parameters and the factors influencing the results obtained. Because the animal groups differed in size, LSM procedure of SAS v.93 was used in the statistical analyses. The following model was used in the statistical analysis of the measurements:

$Y_{\mathrm{ijklm}}=\mu+a_{\mathrm{i}}+b_{\mathrm{j}}+c_{\mathrm{k}}+d_{1}+e_{\mathrm{ijklm}}$

where:

$Y_{\mathrm{ijklm}}$ - analysed trait,

$\mu$ - overall mean,

$a_{i}-$ effect of calving number $(I-V I)$,

$b_{\mathrm{j}}$ - effect of group (I-III),

$c_{\mathrm{k}}$ - effect of study period (I-II),

$d_{1}$ - effect of cow's sire

$e_{\mathrm{ijk} k \mathrm{~m}}$ - random error.

\section{RESULTS AND DISCUSSION}

Examination of the milk yield results (Table 2) showed the highest daily milk production analysed by the Afifarm system in group II (33.94 kg) and the lowest in group III (31.05 kg). The differences between the groups were statistically significant $(P \leq 0.01)$. The lowest 305-day lactation milk yield shown by the Symlek system was found in cows from group III (9696.91 kg) and the highest in those from group I (11 $013.82 \mathrm{~kg}$ ), with a significant difference. The lowest milk urea content was characteristic of animals from the least active group II (192.76 mg/l) and the highest of those from group I (203.19 mg/l). Statistically significant differences between the groups are shown in the table. Milk somatic cell count was also related to the group and activity, ranging from 226.39 thous./ml for group I to 640.16 thous./ml for group III $(P \leq 0.01)$. This state of affairs can be influenced by the age of the animals, because increasing lifespan is accompanied by a decrease in immune resistance (Guliński et al. 2007). This may also result from contraction of disease and disease-induced change in behaviour. Medrano-Galarza et al. (2012) observed during the first day of mastitis that cow activity differed by $0.32 \mathrm{steps} / \mathrm{min}$, which corresponds to a reduction of activity by $19.2 \mathrm{steps} / \mathrm{hour}$.

Table 2. General characteristics - mean values of traits for different experimental groups before the experiment Tabela 2. Charakterystyka ogólna - średnie wartości cech dla poszczególnych grup doświadczalnych przed przeprowadzeniem doświadczenia

\begin{tabular}{|c|c|c|c|c|c|}
\hline \multirow{4}{*}{$\begin{array}{c}\text { No. of } \\
\text { group } \\
\text { Numer } \\
\text { grupy }\end{array}$} & \multicolumn{2}{|c|}{ Afifarm system } & \multicolumn{3}{|c|}{ Symlek system } \\
\hline & $\begin{array}{c}\text { daily milk yield } \\
\text { dobowa }\end{array}$ & $\begin{array}{l}\text { 305-day } \\
\text { production }\end{array}$ & $\begin{array}{l}\text { test-day milk yield } \\
\text { wydainość }\end{array}$ & $\begin{array}{l}\text { urea content } \\
\text { zawartość }\end{array}$ & $\begin{array}{c}\text { SCC } \\
\text { komórki }\end{array}$ \\
\hline & wydajność & produkcja & mleczna - próbny & mocznika [mg/l] & somatyczne \\
\hline & $\begin{array}{c}\text { mleczna [kg] } \\
\bar{x} / \mathrm{sd} \\
\end{array}$ & $\begin{array}{c}\text { z } 305 \text { dni }[\mathrm{kg}] \\
\bar{x} / \mathrm{sd}\end{array}$ & $\begin{array}{c}\text { udój [kg] } \\
\bar{x} / \mathrm{sd}\end{array}$ & $\bar{x} / \mathrm{sd}$ & $\begin{array}{c}\text { [thous. }- \text { tys./ml] } \\
\bar{x} / \mathrm{sd}\end{array}$ \\
\hline I & $31.14^{\mathrm{A}}$ & $11013.82^{A}$ & $40.42^{\mathrm{A}}$ & $203.19^{A B}$ & $226.39^{A}$ \\
\hline$n=2748$ & 9.89 & 1996.30 & 8.15 & 58.44 & 506.59 \\
\hline II & $33.94^{\mathrm{A}}$ & $10440.04^{\mathrm{B}}$ & $30.42^{\mathrm{A}}$ & $192.76^{\mathrm{A}}$ & $579.26^{\mathrm{AB}}$ \\
\hline$n=3128$ & 10.55 & 1557.39 & 14.03 & 37.72 & 730.77 \\
\hline III & $31.05^{\mathrm{A}}$ & $9696.91^{\mathrm{AB}}$ & $32.31^{\mathrm{A}}$ & $200.37^{B}$ & $640.16^{\mathrm{AB}}$ \\
\hline$n=2725$ & 11.01 & 1691.49 & 53.87 & 53.87 & 849.54 \\
\hline
\end{tabular}

Within column - w obrębie kolumny dla: $A A-P \leq 0.01$, aa $-\mathrm{P} \leq 0.05$. 
Group I included animals housed at standard number in the section without outdoor access and subjected to periodic overstocking (Table 3). The presented results indicate that the mean daily milk yield of the cows was high and ranged from 26 to $36 \mathrm{~kg}$ (significant differences at $P \leq 0.01$ ). One exception was the fourth lactation, in which cows produced $19.29 \mathrm{~kg}$ of milk on average. The observed higher content of protein compared to fat, as indicated by the fat to protein ratio, as well as the considerable predominance of ECM compared to FCM, were observed for the first, second and third lactations ( $P \leq 0.01)$. This may be due to the high milk yield of the cows in a given lactation, and the fact that milk fat content is subjected to higher variation than protein content. Pilarska (2014), who studied the productivity of cows during 2007-2009, showed that protein content varied from $3.14 \%$ to $3.74 \%$ and fat content from $3.85 \%$ to $4.51 \%$. The same author also reported a negative correlation between milk yield and the content of milk components, i.e. fat and protein. In the next lactations (fourth, fifth and sixth), the milk fat to protein ratio fell within 1.1-1.3. Fat content increased in relation to protein. A special case is the fifth lactation, in which the highest daily milk $(36.08 \mathrm{~kg}$ ) was obtained and the fat to protein ratio is optimal, with FCM content being higher than ECM content. In the analysed lactations, lactose content was within the physiologically normal range determined by the sixth lactation (4.35\%) and the fifth lactation (4.69\%). Electrical conductivity did not exceed $11 \mathrm{mmho}$. Milking time fluctuated around $7 \mathrm{~min}$ except for the fifth lactation cows, but this may be due to the noticeable relationship between milk yield and milking duration. Statistically significant differences between the analysed lactations in group I are presented in Table 3.

Table 3. General characteristics of daily milk yield traits in experimental group I in different lactations based on the Afifarm system

Tabela 3. Charakterystyka ogólna cech dobowej wydajności mlecznej grupy doświadczalnej I w poszczególnych laktacjach, wg systemu Afifarm

\begin{tabular}{|c|c|c|c|c|c|c|c|c|c|}
\hline $\begin{array}{l}\text { No. of } \\
\text { lactation } \\
\text { Numer } \\
\text { laktacji }\end{array}$ & $\begin{array}{c}\text { milk yield } \\
\text { Wydajność } \\
\text { mleczna } \\
{[\mathrm{kg}]} \\
\bar{x} / \mathrm{sd}\end{array}$ & $\begin{array}{c}\text { Fat } \\
\text { content } \\
\text { Tłuszcz } \\
{[\%]} \\
\bar{x} / \text { sd }\end{array}$ & $\begin{array}{c}\text { Protein } \\
\text { content } \\
\text { Białko } \\
{[\%]} \\
\bar{x} / \mathrm{sd}\end{array}$ & $\begin{array}{c}\text { Fat/protein } \\
\text { ratio } \\
\text { Tłuszcz/białko } \\
\bar{x} / \text { sd }\end{array}$ & $\begin{array}{c}\text { Lactose } \\
\text { content } \\
\text { Laktoza } \\
{[\%]} \\
\bar{x} / \mathrm{sd}\end{array}$ & $\begin{array}{c}\text { Conductivity } \\
\text { of milk } \\
\text { Przewodność } \\
\text { mleka } \\
\text { [mmho] } \\
\bar{x} / \mathrm{sd}\end{array}$ & $\begin{array}{c}\text { Milking } \\
\text { duration } \\
\text { Czas } \\
\text { doju } \\
\text { [min] } \\
\bar{x} / \mathrm{sd}\end{array}$ & $\begin{array}{l}\text { FCM } \\
{[\mathrm{kg}]} \\
\bar{x} / \mathrm{sd}\end{array}$ & $\begin{array}{r}\text { ECM } \\
{[\mathrm{kg}]} \\
\bar{x} / \mathrm{sd}\end{array}$ \\
\hline $\mathrm{I}$ & $35.10^{\mathrm{AB}}$ & $3.19^{A B}$ & $3.50^{A B}$ & $0.92^{\mathrm{Aa}}$ & $4.46^{\mathrm{ABa}}$ & $9.74^{\mathrm{ABC}}$ & $7.18^{\mathrm{ABCa}}$ & $30.70^{\mathrm{A}}$ & $40.30^{\mathrm{AB}}$ \\
\hline $\mathrm{n}=651$ & 7.30 & 0.41 & 0.29 & 0.13 & 0.30 & 1.01 & 1.47 & 6.42 & 8.74 \\
\hline II & $33.23^{\mathrm{Aa}}$ & $3.26^{\mathrm{AC}}$ & $3.51^{\mathrm{CDa}}$ & $0.93^{\mathrm{Ba}}$ & $4.43^{\mathrm{CD}}$ & $10.57^{\mathrm{A}}$ & $6.86^{\mathrm{AC}}$ & $29.48^{\mathrm{A}}$ & $38.50^{A C}$ \\
\hline$n=1416$ & 8.14 & 0.46 & 0.29 & 0.15 & 0.32 & 1.04 & 1.51 & 7.05 & 9.13 \\
\hline III & $27.34^{\mathrm{CB}}$ & $3.25^{\mathrm{CEF}}$ & $3.55^{\mathrm{ACE}}$ & $0.91^{\mathrm{B}}$ & $4.42^{\mathrm{EFab}}$ & $10.94^{\mathrm{AD}}$ & $6.65^{A D}$ & $23.76^{A}$ & $30.51^{A}$ \\
\hline $\mathrm{n}=865$ & 10.29 & 0.67 & 0.32 & 0.20 & 0.35 & 1.21 & 1.51 & 8.38 & 10.28 \\
\hline IV & $19.29^{\mathrm{AD}}$ & $4.10^{\mathrm{AE}}$ & $3.43^{\mathrm{EGH}}$ & $1.19^{\mathrm{AB}}$ & $4.59^{\mathrm{ACEC}}$ & $10.54^{\mathrm{BDa}}$ & $6.45^{\mathrm{B}}$ & $18.54^{\mathrm{A}}$ & $30.83^{C D}$ \\
\hline $\mathrm{n}=117$ & 9.66 & 0.96 & 0.35 & 0.27 & 0.44 & 0.82 & 1.21 & 8.39 & 9.83 \\
\hline $\mathrm{V}$ & $36.08^{\mathrm{BCda}}$ & $3.60^{\mathrm{AEG}}$ & $3.28^{\mathrm{ACG}}$ & $1.11^{\mathrm{AB}}$ & $4.69^{\mathrm{BDFGbC}}$ & $10.35^{\mathrm{Ce}}$ & $7.91^{\mathrm{CDa}}$ & $33.78^{\mathrm{A}}$ & $28.06^{\mathrm{A}}$ \\
\hline $\mathrm{n}=101$ & 15.42 & 0.55 & 0.31 & 0.19 & 0.37 & 1.55 & 1.53 & 14.27 & 16.08 \\
\hline $\mathrm{VI}$ & $26.72^{\mathrm{AD}}$ & $4.27^{\mathrm{BD}}$ & $3.31^{\mathrm{BDFH}}$ & $1.29^{\mathrm{AB}}$ & $4.35^{\mathrm{ACG}}$ & $10.15^{\mathrm{AFa}}$ & $6.67^{\mathrm{C}}$ & $27.59^{\mathrm{A}}$ & $32.01^{\mathrm{BD}}$ \\
\hline $\mathrm{n}=143$ & 6.83 & 0.52 & 0.27 & 0.20 & 0.34 & 0.47 & 1.05 & 5.59 & 7.81 \\
\hline
\end{tabular}

Explanations see Table 1 - Objaśnienia zob. tab. 1.

Group II consisted of cows housed at standard number in the section with outdoor access and subjected to periodic overstocking. This group included the first to fifth lactation animals (Table 4). Group II cows were characterized by high daily milk yield in different lactations, ranging from 22.10 to $39.38 \mathrm{~kg}$ and like in group I, the fifth lactation cows produced the most milk. Differences between the groups were statistically significant. For all the groups, the 
fat/protein ratio did not exceed unity, and the highest value (0.93) occurred in the third lactation. This resulted from the low fat content (lowest for oldest cows, 3.03\%) and the protein content of $3.5 \%-3.7 \%$. In turn, Gnyp et al. (2006) reported that for the cows in fourth and later lactations, fat content was $4.27 \%$ and protein content $3.40 \%$. The normal values for lactose and milk conductivity gave no indication of possible disturbances due to mastitis. Shuster et al. (1991), who observed signs of mastitis, showed that lactose content after induced injection of endotoxins into the udder, decreased by as much as $21 \%$. The difference in milking duration between sixth lactation cows ( $8.48 \mathrm{~min}$ ) and primiparous cows (6.43 min) was around two minutes, although these values differed by 4.86 litres in terms of milk yield $(P \leq 0.01)$. FCM and ECM values reflect the basic data from which they determined.

Table 4. General characteristics of daily milk yield traits in experimental group II in different lactations based on the Afifarm system

Tabela 4. Charakterystyka ogólna cech dobowej wydajności mlecznej grupy doświadczalnej II w poszczególnych laktacjach, wg systemu Afifarm

\begin{tabular}{|c|c|c|c|c|c|c|c|c|c|}
\hline $\begin{array}{l}\text { No. of } \\
\text { lactation } \\
\text { Numer } \\
\text { laktacji }\end{array}$ & $\begin{array}{c}\text { Milk yield } \\
\text { Wydajność } \\
\text { mleczna } \\
{[\mathrm{kg}]} \\
\bar{x} / \mathrm{sd}\end{array}$ & $\begin{array}{c}\text { Fat } \\
\text { content } \\
\text { Tłuszcz } \\
{[\%]} \\
\bar{x} / \text { sd }\end{array}$ & $\begin{array}{c}\text { Protein } \\
\text { content } \\
\text { Białko } \\
{[\%]} \\
\bar{x} / \text { sd }\end{array}$ & $\begin{array}{c}\text { Fat/protein } \\
\text { ratio } \\
\text { Tłuszcz/białko } \\
\bar{x} / \text { sd }\end{array}$ & $\begin{array}{c}\text { Lactose } \\
\text { content } \\
\text { Laktoza } \\
{[\%]} \\
\bar{x} / \mathrm{sd}\end{array}$ & $\begin{array}{c}\text { Conductivity } \\
\text { of milk } \\
\text { Przewodność } \\
\text { mleka } \\
\text { [mmho] } \\
\bar{x} / \mathrm{sd}\end{array}$ & $\begin{array}{c}\text { Milking } \\
\text { duration } \\
\text { Czas } \\
\text { doju } \\
\text { [min] } \\
\bar{x} / \mathrm{sd}\end{array}$ & $\begin{array}{c}\text { FCM } \\
{[\overline{k g}]} \\
\bar{x} / \mathrm{sd}\end{array}$ & $\begin{array}{r}\text { ECM } \\
{[\mathrm{kg}]} \\
\bar{x} / \mathrm{sd}\end{array}$ \\
\hline I & $34.52^{\mathrm{AB}}$ & $3.16^{\mathrm{AB}}$ & $3.50^{\mathrm{AB}}$ & $0.91^{\mathrm{ABa}}$ & $4.50^{\mathrm{A}}$ & $9.67^{A a}$ & $6.43^{\mathrm{AB}}$ & $29.78^{\mathrm{AB}}$ & $39.60^{A}$ \\
\hline $\mathrm{n}=849$ & 6.98 & 0.59 & 0.33 & 0.19 & 0.37 & 0.67 & 1.17 & 5.37 & 8.06 \\
\hline II & $38.91^{\mathrm{A}}$ & $3.07^{A}$ & $3.60^{\mathrm{A}}$ & $0.85^{\mathrm{AC}}$ & $4.42^{\mathrm{A}}$ & $10.29^{A B}$ & $6.92^{\mathrm{Aa}}$ & $33.07^{\mathrm{B}}$ & $45.24^{\mathrm{AB}}$ \\
\hline $\mathrm{n}=974$ & 9.61 & 0.56 & 0.33 & 0.17 & 0.35 & 0.75 & 1.55 & 8.79 & 11.09 \\
\hline III & $32.46^{\mathrm{A}}$ & $3.32^{\mathrm{ABC}}$ & $3.59^{\mathrm{B}}$ & $0.93^{\mathrm{Da}}$ & $4.48^{\mathrm{A}}$ & $10.13^{A B}$ & $7.26^{A}$ & $28.58^{\mathrm{AB}}$ & $38.92^{\mathrm{BC}}$ \\
\hline $\mathrm{n}=1051$ & 11.89 & 0.62 & 0.30 & 0.18 & 0.36 & 0.77 & $\begin{array}{l}1.20 \\
1.52\end{array}$ & 9.34 & 12.86 \\
\hline IV & $22.10^{A}$ & $3.17^{\mathrm{C}}$ & $3.76^{\mathrm{AB}}$ & $0.84^{\mathrm{BDE}}$ & $4.29^{\mathrm{AB}}$ & $11.14^{\mathrm{AB}}$ & $7.20^{\mathrm{BCa}}$ & $18.45^{\mathrm{AB}}$ & $25.32^{\mathrm{AC}}$ \\
\hline$n=304$ & 10.54 & 0.72 & 0.33 & 0.22 & 0.33 & 0.84 & 1.64 & 7.52 & 10.78 \\
\hline $\mathrm{V}$ & $39.38^{B}$ & $3.03^{\mathrm{BC}}$ & $3.32^{\mathrm{AB}}$ & $0.90^{\mathrm{CE}}$ & $4.46^{\mathrm{B}}$ & $9.81^{\mathrm{Ba}}$ & $8.48^{A C}$ & $33.00^{A}$ & $42.55^{\mathrm{AC}}$ \\
\hline $\mathrm{n}=141$ & 8.82 & 0.53 & 0.38 & 0.17 & 0.52 & 0.45 & 1.06 & 7.41 & 10.54 \\
\hline
\end{tabular}

Explanations see Table 1 - Objaśnienia zob. tab. 1.

Table 5 presents the production results of group III (cows housed at standard number in the section with outdoor access and intended for increasing the stocking density in groups I and II) with regard to lactation number. The lowest mean daily milk yield was characteristic of fifth lactation cows $(25.87 \mathrm{~kg})$, which also showed the shortest milking duration compared to the other lactation groups $(P \leq 0.01)$. These observations are supported by Edwards et al. (2014), who found that with an increase in milk production level from 7.23 to $9.83 \mathrm{~kg} / \mathrm{milking}$, milking duration increased by 311.6 and 356.7 seconds, respectively. The highest fat content was obtained by oldest (sixth lactation) cows (3.52\%) and the lowest by youngest (first lactation) cows (3.07\%), which was statistically confirmed at $P \leq 0.01$. Different results were obtained by Pilarska (2014), who showed the lowest fat content during third lactation $(4.07 \%)$ and the highest in fourth lactation cows (4.28\%). Primiparous cows had a milk yield of $4.12 \%$. In the results presented in the table, the milk of sixth lactation cows had the lowest protein percentage of $3.29 \%(P \leq 0.01)$. Kuczyńska et al. (2015) found the lowest protein content in primiparous cows $(3.39 \%)$ and the highest in the group of third and later lactation animals $(3.47 \%)$. Third and fourth lactation cows were characterized by the highest content of protein (3.56-3.58\%) and lactose (4.41-4.47\%). Electrical conductivity of milk, although at a similar level for the entire group III, showed statistically significant differences. The other parameters and statistical analysis are shown in Table 5. 
Table 5. General characteristics of daily milk yield traits in experimental group III in different lactations based on the Afifarm system

Tabela 5. Charakterystyka ogólna cech dobowej wydajności mlecznej grupy doświadczalnej III w poszczególnych laktacjach, wg systemu Afifarm

\begin{tabular}{|c|c|c|c|c|c|c|c|c|c|}
\hline $\begin{array}{l}\text { No. of } \\
\text { lactation } \\
\text { Numer } \\
\text { laktacji }\end{array}$ & $\begin{array}{c}\text { Milk yield } \\
\text { Wydajność } \\
\text { mleczna } \\
{[\mathrm{kg}]} \\
\bar{x} / \mathrm{sd}\end{array}$ & $\begin{array}{c}\text { Fat } \\
\text { content } \\
\text { Tłuszcz } \\
{[\%]} \\
\bar{x} / \text { sd }\end{array}$ & $\begin{array}{c}\text { Protein } \\
\text { content } \\
\text { Białko } \\
{[\%]} \\
\bar{x} / \mathrm{sd}\end{array}$ & $\begin{array}{c}\text { Fat/protein } \\
\text { ratio } \\
\text { Tłuszcz/ } \\
\text { /białko } \\
\bar{x} / \text { sd }\end{array}$ & $\begin{array}{c}\text { Lactose } \\
\text { content } \\
\text { Laktoza } \\
{[\%]} \\
\bar{x} / \mathrm{sd}\end{array}$ & $\begin{array}{c}\text { Conductivity } \\
\text { of milk } \\
\text { Przewodność } \\
\text { mleka } \\
\text { [mmho] } \\
\bar{x} / \mathrm{sd}\end{array}$ & $\begin{array}{c}\text { Milking } \\
\text { duration } \\
\text { Czas doju } \\
\text { [min] } \\
\bar{x} / \text { sd }\end{array}$ & $\begin{array}{c}\text { FCM } \\
{[\mathrm{kg}]} \\
\bar{x} / \mathrm{sd}\end{array}$ & $\begin{array}{l}\text { ECM } \\
{[\mathrm{kg}]} \\
\bar{x} / \mathrm{sd}\end{array}$ \\
\hline I & $31.38^{A B C}$ & $3.07^{\mathrm{ABC}}$ & $3.55^{\mathrm{Aa}}$ & $0.86^{\mathrm{ABC}}$ & $4.41^{\mathrm{A}}$ & $10.01^{\mathrm{Aa}}$ & $6.88^{A}$ & $27.35^{\mathrm{ABC}}$ & 35.09 \\
\hline $\mathrm{n}=1661$ & 9.19 & 0.50 & 0.32 & 0.16 & 0.37 & 1.06 & 1.81 & 8.43 & 10.51 \\
\hline II & $34.99^{A}$ & $3.22^{\mathrm{A}}$ & $3.42^{\mathrm{ABC}}$ & $0.94^{\mathrm{A}}$ & $4.41^{B}$ & $9.97^{\mathrm{BC}}$ & $6.47^{\mathrm{AB}}$ & $30.19^{A D}$ & $39.21^{\mathrm{A}}$ \\
\hline $\mathrm{n}=777$ & 12.38 & 0.59 & 0.32 & 0.18 & 0.35 & 0.67 & 1.81 & 9.82 & 13.66 \\
\hline III & $34.65^{\mathrm{BD}}$ & $3.40^{\mathrm{AD}}$ & $3.56^{\mathrm{BD}}$ & $0.95^{\mathrm{BD}}$ & $4.47^{\mathrm{ABCD}}$ & $10.38^{\mathrm{ABC}}$ & $7.54^{\mathrm{Aa}}$ & $30.48^{\mathrm{BEF}}$ & $40.53^{\mathrm{AB}}$ \\
\hline $\mathrm{n}=814$ & 11.26 & 0.73 & 0.31 & 0.22 & 0.34 & 0.79 & 1.45 & 7.83 & 11.78 \\
\hline IV & $28.80^{\mathrm{ADE}}$ & $3.29^{\mathrm{BD}}$ & $3.58^{\mathrm{CEa}}$ & $0.91^{A D E}$ & $4.41^{\mathrm{C}}$ & $10.20^{\mathrm{CDa}}$ & $8.96^{\mathrm{AC}}$ & $25.31^{\mathrm{AE}}$ & $33.52^{\mathrm{B}}$ \\
\hline$n=424$ & 7.42 & 0.59 & 032 & 0.18 & 0.36 & 0.81 & 1.02 & 6.51 & 8.20 \\
\hline $\mathrm{V}$ & $25.87^{\mathrm{ADE}}$ & $3.33^{C}$ & $3.48^{\mathrm{ADE}}$ & $0.96^{\mathrm{CEF}}$ & $4.39^{D}$ & $10.95^{\mathrm{ADE}}$ & $5.36^{\mathrm{AC}}$ & $24.25^{\mathrm{CDFG}}$ & 29.26 \\
\hline$n=129$ & 11.78 & 0.41 & 0.29 & 0.13 & 0.39 & 0.46 & 1.32 & 10.69 & 12.37 \\
\hline $\mathrm{VI}$ & $35.28^{\mathrm{CE}}$ & $3.52^{\mathrm{ABC}}$ & $3.29^{\mathrm{ABE}}$ & $1.08^{\mathrm{ADF}}$ & $4.33^{\mathrm{ABC}}$ & $10.06^{\mathrm{CE}}$ & $7.71^{\mathrm{BCa}}$ & $32.79^{\mathrm{ABG}}$ & 42.42 \\
\hline$n=126$ & 10.21 & 0.55 & 0.26 & 0.21 & 0.35 & 0.47 & 1.60 & 6.98 & 10.07 \\
\hline
\end{tabular}

Explanations see Table 1 - Objaśnienia zob. tab. 1.

The course of the experiment, especially in the second experimental period had an effect on the production results of the investigated group of cows (Table 6). Milk yield considerably decreased, while fat and protein percentage increased $(P \leq 0.01)$. The decrease in milk yield is supported by Krawczel et al. (2012). Loker et al. (2012) showed that milk yield was negatively correlated to milk fat $(r=-0.51)$ and protein content $(r=-0.55)$. Also the phenotypic correlations were negative at $r=-0.31$ for the relationship between milk yield and fat content, and $r=-0.38$ between milk yield and protein content. The content of lactose, which is a stable component of milk, decreased below $4.4 \%$. Conductivity remained at a very similar level. Milking duration decreased with the decreasing milk yield ( $P \leq 0.01)$. The fat content examined during the first experimental period considerably decreased in relation to the observed low milk yield, but when these values are converted to fat-corrected milk (FCM), the differences are not so great, but highly significant. Clear changes occurred in the second experimental period, when FCM decreased from 28.5 to $24.5 \mathrm{~kg}$. In the first experimental group, in which animals had no outdoor access, the short change in housing conditions had little effect on the production parameters (Table 6). A considerable decrease $(8.92 \mathrm{~kg})$ in daily milk production was observed in the second experimental period when twice as many cows were introduced compared to the first period ( $P \leq 0.01)$. Wang et al. (2016) observed that when stocking density increased from 100 to $129 \%$, milk yield increased from 31.91 to $33.11 \mathrm{~kg}$. De Vries et al. (2016) reported that for a density of $150 \%$, daily milk yield per cow decreased from 28.48 to $26.38 \mathrm{~kg}$. ECM milk production increased by $1.12 \mathrm{~kg}$, and $3.5 \%$ FCM milk yield by $0.99 \mathrm{~kg}$. Protein content increased by $0.04 \%$ and fat content by $0.02 \%$. In the presented study, there were also fluctuations in the composition of the analysed milk, with statistically significant differences. 
Table 6. Characteristics of daily milk yield traits in experimental group I in different study periods Tabela 6. Charakterystyka cech dobowej wydajności mlecznej grupy doświadczalnej I w poszczególnych okresach badawczych

\begin{tabular}{|c|c|c|c|c|c|c|c|c|c|}
\hline $\begin{array}{l}\text { Study period } \\
\text { Okres } \\
\text { badawczy }\end{array}$ & $\begin{array}{c}\text { Milk yield } \\
\text { Wydajność } \\
\text { mleczna } \\
{[\mathrm{kg}]} \\
\bar{x} / \mathrm{sd}\end{array}$ & $\begin{array}{c}\text { Fat } \\
\text { content } \\
\text { Tłuszcz } \\
{[\%]} \\
\bar{x} / \mathrm{sd}\end{array}$ & $\begin{array}{c}\text { Protein } \\
\text { content } \\
\text { Białko } \\
{[\%]} \\
\bar{x} / \mathrm{sd}\end{array}$ & $\begin{array}{l}\text { Fat/protein } \\
\text { ratio } \\
\text { Tłuszcz/ } \\
\text { /białko } \\
\bar{x} / \text { sd }\end{array}$ & $\begin{array}{c}\text { Lactose } \\
\text { content } \\
\text { Laktoza } \\
{[\%]} \\
\bar{x} / \mathrm{sd}\end{array}$ & $\begin{array}{l}\text { Conductivity } \\
\text { of milk } \\
\text { Przewodność } \\
\text { mleka } \\
\text { [mmho] } \\
\bar{x} / \mathrm{sd} \\
\end{array}$ & $\begin{array}{c}\text { Milking } \\
\text { duration } \\
\text { Czas doju } \\
\text { [min] } \\
\bar{x} / \mathrm{sd}\end{array}$ & $\begin{array}{l}\text { FCM } \\
{[\mathrm{kg}]} \\
\bar{x} / \mathrm{sd}\end{array}$ & $\begin{array}{l}\text { ECM } \\
{[\mathrm{kg}]} \\
\bar{x} / \mathrm{sd}\end{array}$ \\
\hline $\begin{array}{l}\text { Comparison } \\
\text { period }\end{array}$ & $32.10^{\mathrm{AB}}$ & $3.35^{\mathrm{A}}$ & $3.50^{\mathrm{Aa}}$ & $0.96^{\mathrm{A}}$ & $4.47^{\mathrm{A}}$ & 10.41 & $6.91^{\mathrm{A}}$ & $28.58^{\mathrm{A}}$ & $36.80^{\mathrm{A}}$ \\
\hline $\begin{array}{l}\text { Porównawczy } \\
n=2221\end{array}$ & 9.10 & 0.63 & 0.31 & 0.20 & 0.35 & 1.20 & 1.49 & 8.43 & 10.27 \\
\hline $\begin{array}{l}\text { Experimental } \\
\text { period }\end{array}$ & $32.28^{\mathrm{B}}$ & $3.17^{\mathrm{A}}$ & $3.47^{\mathrm{Ba}}$ & $0.91^{\mathrm{A}}$ & $4.44^{\mathrm{B}}$ & 10.44 & $6.83^{B}$ & $28.27^{\mathrm{B}}$ & $37.24^{\mathrm{B}}$ \\
\hline $\begin{array}{l}\text { Doświadczalny } 1 \\
n=790\end{array}$ & 7.87 & 0.42 & 0.28 & 0.14 & 0.29 & 1.03 & 1.43 & 0.00 & 9.05 \\
\hline $\begin{array}{l}\text { Experimental } \\
\text { period }\end{array}$ & $23.18^{A}$ & $3.63^{\mathrm{A}}$ & $3.59^{A B}$ & $1.01^{\mathrm{A}}$ & $4.29^{A B}$ & 10.43 & $6.55^{\mathrm{AB}}$ & $24.58^{\mathrm{AB}}$ & $28.13^{\mathrm{AB}}$ \\
\hline $\begin{array}{l}\text { Doświadczalny } 2 \\
n=282\end{array}$ & 9.19 & 0.68 & 0.33 & 0.21 & 0.36 & 1.40 & 1.62 & 8.07 & 10.61 \\
\hline
\end{tabular}

Explanations see Table 1 - Objaśnienia zob. tab. 1.

In the second group with outdoor access, the production parameters also showed changes during the experiment (Table 7). Milk yield decreased but to a smaller extent than in the first group. The differences were statistically significant $(P \leq 0.01)$. During the first experimental period, cows produced most milk $(35.96 \mathrm{~kg})$ but the least fat percentage $(P \leq 0.01)$. The result was most favourable when converted to FCM and also to ECM, despite the fact that the highest protein content was observed during the second experimental period $(3.72 \%)$. The observed decrease in daily milk production in the second experimental period by $7.46 \mathrm{~kg}$ in relation to the comparison period $(P \leq 0.01)$ and by $8.91 \mathrm{~kg}$ in relation to the first period $(P \leq 0.01)$ is due to overstocking, despite the fact that the group had outdoor access. Falk et al. (2012), who studied the behaviour of cattle in a free-stall barn with pasture access, found that under unfavourable humidity and thermal conditions, cows prefer staying outdoors at night, and staying in the barn during the day even it is overstocked. This behaviour may explain why despite outdoor access, the cows experience overstocking stress, which results in reduced milk yield. In the study presented in the table, the fat to protein ratio did not exceed unity throughout the experiment. Also in milking session II, lactose content decreased as did electrical conductivity of milk and milking duration.

The milk yield characteristics of the cows from group III in the analysed periods are presented in Table 8. The highest fat-corrected milk (FCM) and fat- and protein-corrected milk (ECM) yields were obtained by cows during the first experimental period, 29.58 and $39.19 \mathrm{~kg}$, respectively $(\mathrm{P} \leq 0.01)$. This was related to the highest milk yield $(34.59 \mathrm{~kg})$, despite the lowest milk fat $(3.11 \%)$ and protein content $(3.50 \%)$. The fat to protein ratio remained low between 0.91 and 0.96 . As in the other experimental groups (I-II), lactose content decreased slightly during the second experimental period, whereas electrical conductivity increased. This could be associated with the presence of subclinical or clinical mastitis, which increases the electrical conductivity of milk. Wang et al. (2016) observed that the milk somatic count of the cows increased by $12.26 \%$ when stocking density was increased to $124 \%$. Milking duration during that period was higher than during the 
comparison period despite the lower milk yield. Berry et al. (2003) showed that although this relationship is strong (Pearson's correlation coefficient of 0.48 ), it is not the only one to affect milking speed. Other factors are the content of different milk components: fat, protein, lactose, somatic cells, for which the respective coefficients of correlation were $r=-0.02$, $r=-0.12, r=0.05, r=-0.05$.

Table 7. Characteristics of daily milk yield traits in experimental group II in different study periods Tabela 7. Charakterystyka cech dobowej wydajności mlecznej grupy doświadczalnej II w poszczególnych okresach badawczych

\begin{tabular}{|c|c|c|c|c|c|c|c|c|c|}
\hline $\begin{array}{c}\text { Study period } \\
\text { Okres badawczy }\end{array}$ & $\begin{array}{c}\text { Milk yield } \\
\text { Wydajność } \\
\text { mleczna } \\
{[\mathrm{kg}]} \\
\bar{x} / \mathrm{sd}\end{array}$ & $\begin{array}{c}\text { Fat } \\
\text { content } \\
\text { Tłuszcz } \\
{[\%]} \\
\bar{x} / \mathrm{sd}\end{array}$ & $\begin{array}{c}\text { Protein } \\
\text { content } \\
\text { Białko } \\
{[\%]} \\
\bar{x} / \mathrm{sd}\end{array}$ & $\begin{array}{c}\text { Fat/protein } \\
\text { ratio } \\
\text { Tłuszcz/ } \\
\text { /białko } \\
\bar{x} / \text { sd }\end{array}$ & $\begin{array}{c}\text { Lactose } \\
\text { content } \\
\text { Laktoza } \\
{[\%]} \\
\bar{x} / \mathrm{sd}\end{array}$ & $\begin{array}{c}\text { Conductivity } \\
\text { of milk } \\
\text { Przewodność } \\
\text { mleka } \\
\text { [mmho] } \\
\bar{x} / \mathrm{sd}\end{array}$ & $\begin{array}{c}\text { Milking } \\
\text { duration } \\
\text { Czas doju } \\
\text { [min] } \\
\bar{x} / \mathrm{sd}\end{array}$ & $\begin{array}{c}\text { FCM } \\
{[\mathrm{kg}]} \\
\bar{x} / \mathrm{sd}\end{array}$ & $\begin{array}{c}\text { ECM } \\
{[\mathrm{kg}]} \\
\bar{x} / \mathrm{sd}\end{array}$ \\
\hline $\begin{array}{l}\text { Comparison } \\
\text { period }\end{array}$ & $34.51^{\mathrm{A}}$ & $3.18^{A}$ & $3.57^{\mathrm{A}}$ & $0.89^{A}$ & $4.45^{\mathrm{A}}$ & $10.08^{a}$ & $6.98^{A}$ & $29.66^{A}$ & $40.12^{A}$ \\
\hline $\begin{array}{l}\text { Porównawczy } \\
n=2214\end{array}$ & 11.16 & 0.62 & 0.33 & 0.20 & 0.37 & 0.84 & 1.50 & 9.19 & 12.51 \\
\hline $\begin{array}{l}\text { Experimental } \\
\text { period }\end{array}$ & $35.96^{\mathrm{A}}$ & $3.07^{\mathrm{A}}$ & $3.54^{\mathrm{A}}$ & $0.86^{A}$ & $4.47^{B}$ & $10.11^{b}$ & $6.98^{B}$ & $30.53^{A}$ & $41.39^{A}$ \\
\hline $\begin{array}{l}\text { Doświadczalny } 1 \\
\mathrm{n}=815\end{array}$ & 9.77 & 0.54 & 0.32 & 0.17 & 0.36 & 0.70 & 1.44 & 8.41 & 11.18 \\
\hline $\begin{array}{l}\text { Experimental } \\
\text { period }\end{array}$ & $27.05^{\mathrm{A}}$ & $3.47^{\mathrm{A}}$ & $3.72^{\mathrm{A}}$ & $0.94^{\mathrm{A}}$ & $4.37^{\mathrm{AB}}$ & $9.64^{\mathrm{ab}}$ & $6.62^{\mathrm{AB}}$ & $24.58^{\mathrm{A}}$ & $33.56^{A}$ \\
\hline $\begin{array}{l}\text { Doświadczalny } 2 \\
n=288\end{array}$ & 9.53 & 0.62 & 0.35 & 0.18 & 0.34 & 0.70 & 1.56 & 7.71 & 10.90 \\
\hline
\end{tabular}

Explanations see Table 1 - Objaśnienia zob. tab. 1.

Table 8. Characteristics of daily milk yield traits in experimental group III in different study periods Tabela 8.Charakterystyka cech dobowej wydajności mlecznej grupy doświadczalnej III w poszczególnych okresach badawczych

\begin{tabular}{|c|c|c|c|c|c|c|c|c|c|}
\hline $\begin{array}{c}\text { Study period } \\
\text { Okres badawczy }\end{array}$ & $\begin{array}{c}\text { Milk yield } \\
\text { Wydajność } \\
\text { mleczna } \\
{[\mathrm{kg}]} \\
\bar{x} / \mathrm{sd}\end{array}$ & $\begin{array}{c}\text { Fat content } \\
\text { Tłuszcz } \\
{[\%]} \\
\bar{x} / \mathrm{sd}\end{array}$ & $\begin{array}{c}\text { Protein } \\
\text { content } \\
\text { Białko } \\
{[\%]} \\
\bar{x} / \mathrm{sd}\end{array}$ & $\begin{array}{c}\text { Fat/protein } \\
\text { ratio } \\
\text { Tłuszcz/ } \\
\text { /białko } \\
\bar{x} / \text { sd }\end{array}$ & $\begin{array}{c}\text { Lactose } \\
\text { content } \\
\text { Laktoza } \\
{[\%]} \\
\bar{x} / \mathrm{sd}\end{array}$ & $\begin{array}{c}\text { Conductivity } \\
\text { of milk } \\
\text { Przewodnoś } \\
\text { ć mleka } \\
\text { [mmho] } \\
\bar{x} / \mathrm{sd}\end{array}$ & $\begin{array}{c}\text { Milking } \\
\text { duration } \\
\text { Czas doju } \\
\text { [min] } \\
\bar{x} / \mathrm{sd}\end{array}$ & $\begin{array}{l}\text { FCM } \\
{[\mathrm{kg}]} \\
\bar{x} / \mathrm{sd}\end{array}$ & $\begin{array}{c}\text { ECM } \\
{[\mathrm{kg}]} \\
\bar{x} / \mathrm{sd}\end{array}$ \\
\hline $\begin{array}{l}\text { Comparison } \\
\text { period } \\
\text { Porównawczy } \\
\mathrm{n}=2609\end{array}$ & $\begin{array}{l}32.48^{A} \\
10.54\end{array}$ & $\begin{array}{l}3.22^{\mathrm{A}} \\
0.61\end{array}$ & $\begin{array}{l}3.52^{\mathrm{A}} \\
0.33\end{array}$ & $\begin{array}{l}0.91^{\mathrm{A}} \\
0.19\end{array}$ & $\begin{array}{l}4.43^{\mathrm{A}} \\
0.38\end{array}$ & $\begin{array}{c}10.09^{a} \\
0.94\end{array}$ & $\begin{array}{l}6.91^{\mathrm{A}} \\
1.81^{\mathrm{N}}\end{array}$ & $\begin{array}{c}28.52^{\mathrm{A}} \\
8.80\end{array}$ & $\begin{array}{l}36.70^{\mathrm{A}} \\
11.79\end{array}$ \\
\hline $\begin{array}{l}\text { Experimental } \\
\text { period } \\
\text { Doświadczalny } 1 \\
\mathrm{n}=956\end{array}$ & $\begin{array}{c}34.59^{A} \\
9.68\end{array}$ & $\begin{array}{l}3.11^{\mathrm{A}} \\
0.51\end{array}$ & $\begin{array}{l}3.50^{\mathrm{B}} \\
0.30\end{array}$ & $\begin{array}{l}0.89^{A} \\
0.16\end{array}$ & $\begin{array}{l}4.44^{\mathrm{B}} \\
0.31\end{array}$ & $\begin{array}{c}10.09^{b} \\
0.77\end{array}$ & $\begin{array}{l}7.18^{\mathrm{Aa}} \\
1.62\end{array}$ & $\begin{array}{c}29.58^{\mathrm{A}} \\
7.70\end{array}$ & $\begin{array}{l}39.19^{A} \\
10.43\end{array}$ \\
\hline $\begin{array}{l}\text { Experimental } \\
\text { period } \\
\text { Doświadczalny } 2 \\
\mathrm{n}=367\end{array}$ & $\begin{array}{l}26.46^{A} \\
10.64\end{array}$ & $\begin{array}{l}3.44^{\mathrm{A}} \\
0.70\end{array}$ & $\begin{array}{l}3.61^{A B} \\
0.32\end{array}$ & $\begin{array}{l}0.96^{A} \\
0.21\end{array}$ & $\begin{array}{l}4.33^{\mathrm{AB}} \\
0.34\end{array}$ & $\begin{array}{c}10.31^{\mathrm{ab}} \\
1.20\end{array}$ & $\begin{array}{l}6.96^{a} \\
2.08\end{array}$ & $\begin{array}{c}24.39^{A} \\
9.33\end{array}$ & $\begin{array}{l}31.58^{A} \\
12.12\end{array}$ \\
\hline
\end{tabular}

Explanations see Table 1 - Objaśnienia zob. tab. 1.

The results of milk production traits for different study groups in the comparison period are shown in Table 9. Although the study groups had production results at a similar level, the differences between them were mostly highly significant. This concerned the milk yield, electrical conductivity, lactose content, FCM, protein percentage. There were also differences 
in fat content, milk yield, ECM and fat to protein ratio. The second study group had the highest production with daily milk yield of $34.60 \mathrm{~kg}$ and ECM value of $40.21 \mathrm{~kg}$, but at the same time the milk of cows from this group had the lowest fat content $(3.18 \%)$. The longer milking duration resulted from the higher productivity of cows from this group. Differences in relation to the other groups were statistically significant. On the other hand, Wójcik and Rudziński (2014) report that compared to the other animals under study, such cows are characterized by the highest daily activity, which also has a direct effect on the milk production level. The lowest milk production was characteristic of group I which was kept without outdoor access, i.e. in adverse housing conditions. This is not confirmed by Radkowska (2012), who achieved $0.7 \mathrm{~kg}$ higher (statistically significant) milk yield from the cows without outdoor access. However, the chemical composition of milk was less favourable. Cows with outdoor access had a higher content of solids $(13.34 \%)$, protein $(3.48 \%)$, fat $(4.19 \%)$ and lactose (4.80), whereas milk from the animals without outdoor access had the following composition: solids (12.31\%), protein (3.35\%), fat $(3.49 \%)$, lactose $(4.73 \%)$.

Table 9. Characteristics of daily milk yield in cows from different study groups during the comparison period Tabela 9.Charakterystyka dobowej wydajności mlecznej krów w poszczególnych grupach badawczych w okresie porównawczym

\begin{tabular}{|c|c|c|c|c|c|c|c|c|c|}
\hline $\begin{array}{c}\text { Study } \\
\text { period } \\
\text { Grupa } \\
\text { badawcza }\end{array}$ & $\begin{array}{c}\text { Milk yield } \\
\text { Wydajność } \\
\text { mleczna } \\
{[\mathrm{kg}]} \\
\bar{x} / \mathrm{sd}\end{array}$ & $\begin{array}{c}\text { Fat content } \\
\text { Tłuszcz } \\
{[\%]} \\
\bar{x} / \mathrm{sd}\end{array}$ & $\begin{array}{c}\text { Protein } \\
\text { content } \\
\text { Białko } \\
{[\%]} \\
\bar{x} / \text { sd }\end{array}$ & $\begin{array}{c}\text { Fat/protein } \\
\text { ratio } \\
\text { Tłuszcz/ } \\
\text { /białko } \\
\bar{x} / \text { sd }\end{array}$ & $\begin{array}{c}\text { Lactose } \\
\text { content } \\
\text { Laktoza } \\
{[\%]} \\
\bar{x} / \mathrm{sd} \\
\end{array}$ & $\begin{array}{c}\text { Conductivity } \\
\text { of milk } \\
\text { Przewodność } \\
\text { mleka } \\
{[\mathrm{mmho}]} \\
\bar{x} / \mathrm{sd} \\
\end{array}$ & $\begin{array}{c}\text { Milking } \\
\text { duration } \\
\text { Czas doju } \\
\text { [min] } \\
\bar{x} / \mathrm{sd}\end{array}$ & $\begin{array}{c}\text { FCM } \\
{[\mathrm{kg}]} \\
\bar{x} / \mathrm{sd}\end{array}$ & $\begin{array}{c}\text { ECM } \\
{[\mathrm{kg}]} \\
\bar{x} / \mathrm{sd}\end{array}$ \\
\hline $\mathrm{I}$ & $32.22^{A}$ & $3.35^{\mathrm{AB}}$ & $3.50^{\mathrm{Aa}}$ & $0.96^{\mathrm{A}}$ & $4.47^{\mathrm{A}}$ & $10.41^{\mathrm{A}}$ & 6.92 & $28.68^{\mathrm{A}}$ & $36.94^{\mathrm{A}}$ \\
\hline $\mathrm{n}=2181$ & 9.88 & 0.63 & 0.31 & 0.20 & 0.34 & 1.20 & 1.48 & 8.40 & 10.22 \\
\hline II & $34.60^{\mathrm{AB}}$ & $3.18^{\mathrm{Aa}}$ & $3.57^{\mathrm{AB}}$ & $0.89^{A}$ & $4.45^{a}$ & $10.08^{A}$ & 6.99 & $29.71^{A B}$ & $40.21^{\mathrm{AB}}$ \\
\hline$n=2176$ & 11.19 & 0.62 & 0.33 & 0.20 & 0.37 & 0.84 & 1.51 & 9.22 & 12.55 \\
\hline III & $32.58^{\mathrm{B}}$ & $3.22^{\mathrm{Ba}}$ & $3.52^{\mathrm{Ba}}$ & $0.91^{\mathrm{A}}$ & $4.43^{\mathrm{Aa}}$ & $10.09^{A}$ & 6.91 & $28.61^{\mathrm{B}}$ & $36.79^{\mathrm{B}}$ \\
\hline $\mathrm{n}=2559$ & 10.52 & 0.61 & 0.33 & 0.19 & 0.38 & 0.94 & 1.81 & 8.77 & 11.77 \\
\hline
\end{tabular}

Explanations see Table 1 - Objaśnienia zob. tab. 1.

The first experimental period, during which the first group of 5 cows each was introduced into groups I and II, thus increasing stocking density, caused considerable differences in the results among the study groups (Table 10). In all the groups, fat percentage decreased $(P \leq 0.01)$. The highest decrease, by $0.22 \%$, was noted in group $I$, which was also characterized by the lowest milk yield and milk protein content (3.46\%). Different results were obtained in a study by Krawczel et al. (2012), in which fat content decreased by $0.04 \%$, and protein content increased by $0.01 \%$. In the presented study, the low fat/protein ratio persisted, whereas lactose content remained within normal range Thus, the increase in density of the group without outdoor access caused the largest changes in production ( $P \leq 0.01$ ). Group II retained the high level of milk production $(34.38 \mathrm{~kg})$ despite the introduction of additional 5 cows into the group. The highest level of lactose and two production indicators (FCM and ECM) was observed. Group III, which was subjected to periodic destocking, because 10 animals were removed from it, did not achieve higher production than group II, despite the statistically significant differences. However, this group achieved the highest level of fat and protein in milk. There were also changes in electrical conductivity of milk and milking duration to the advantage of this group. 
Table 10. Characteristics of daily milk yield in cows from different study groups during the experimental period I

Tabela 10. Charakterystyka dobowej wydajności mlecznej krów w poszczególnych grupach badawczych w okresie doświadczalnym I

\begin{tabular}{|c|c|c|c|c|c|c|c|c|c|}
\hline $\begin{array}{c}\text { Study } \\
\text { period } \\
\text { Grupa } \\
\text { badawcza }\end{array}$ & $\begin{array}{c}\text { Milk yield } \\
\text { Wydajność } \\
\text { mleczna } \\
{[\mathrm{kg}]} \\
\bar{x} / \mathrm{sd}\end{array}$ & $\begin{array}{c}\text { Fat } \\
\text { content } \\
\text { Tłuszcz } \\
{[\%]} \\
\bar{x} / \text { sd }\end{array}$ & $\begin{array}{c}\text { Protein } \\
\text { content } \\
\text { Białko } \\
{[\%]} \\
\bar{x} / \mathrm{sd}\end{array}$ & $\begin{array}{c}\text { Fat/protein } \\
\text { ratio } \\
\text { Tłuszcz/ } \\
\text { /białko } \\
\bar{x} / \text { sd }\end{array}$ & $\begin{array}{c}\text { Lactose } \\
\text { content } \\
\text { Laktoza } \\
{[\%]} \\
\bar{x} / \mathrm{sd}\end{array}$ & $\begin{array}{c}\text { Conductivity } \\
\text { of milk } \\
\text { Przewodność } \\
\text { mleka } \\
\text { [mmho] } \\
\bar{x} / \mathrm{sd} \\
\end{array}$ & $\begin{array}{c}\text { Milking } \\
\text { duration } \\
\text { Czas doju } \\
\text { [min] } \\
\bar{x} / \mathrm{sd}\end{array}$ & $\begin{array}{c}\text { FCM } \\
{[\mathrm{kg}]} \\
\bar{x} / \mathrm{sd}\end{array}$ & $\begin{array}{c}\text { ECM } \\
{[\mathrm{kg}]} \\
\bar{x} / \mathrm{sd}\end{array}$ \\
\hline $\begin{array}{c}\mathrm{I} \\
\mathrm{n}=1028\end{array}$ & $\begin{array}{c}32.94^{\mathrm{A}} \\
8.48\end{array}$ & $\begin{array}{l}3.13^{\mathrm{a}} \\
0.45\end{array}$ & $\begin{array}{l}3.46^{\mathrm{AB}} \\
0.29\end{array}$ & $\begin{array}{l}0.90^{\text {Aa }} \\
0.15\end{array}$ & $\begin{array}{l}4.42^{\mathrm{A}} \\
0.31\end{array}$ & $\begin{array}{c}10.40^{\mathrm{A}} \\
0.98\end{array}$ & & $\begin{array}{c}28.42^{\text {Aa }} \\
7.37\end{array}$ & $\begin{array}{c}37.70^{A} \\
9.63\end{array}$ \\
\hline $\begin{array}{c}\text { II } \\
n=951\end{array}$ & $\begin{array}{l}34.38^{A B} \\
10.16\end{array}$ & $\begin{array}{l}3.13^{A} \\
0.54\end{array}$ & $\begin{array}{l}3.54^{\mathrm{A}} \\
0.31\end{array}$ & $\begin{array}{l}0.88^{\mathrm{A}} \\
0.17\end{array}$ & $\begin{array}{l}4.47^{A} \\
0.36\end{array}$ & $\begin{array}{c}10.14^{\mathrm{A}} \\
0.73\end{array}$ & $\begin{array}{l}6.92^{\mathrm{B}} \\
1.44\end{array}$ & $\begin{array}{c}29.40^{\mathrm{A}} \\
8.60\end{array}$ & $\begin{array}{l}39.74^{\mathrm{AB}} \\
11.61\end{array}$ \\
\hline $\begin{array}{c}\text { III } \\
\mathrm{n}=357\end{array}$ & $\begin{array}{c}33.02^{\mathrm{B}} \\
7.37\end{array}$ & $\begin{array}{l}3.20^{\mathrm{Aa}} \\
0.52\end{array}$ & $\begin{array}{l}3.55^{\mathrm{B}} \\
0.32\end{array}$ & $\begin{array}{l}0.90^{\mathrm{a}} \\
0.15\end{array}$ & $\begin{array}{l}4.45 \\
0.31\end{array}$ & $\begin{array}{l}9.75^{\mathrm{A}} \\
0.74\end{array}$ & $\begin{array}{l}7.37^{\mathrm{AB}} \\
1.63\end{array}$ & $\begin{array}{c}29.41^{a} \\
6.47\end{array}$ & $\begin{array}{c}37.74^{\mathrm{B}} \\
8.21\end{array}$ \\
\hline
\end{tabular}

Explanations see Table 1 - Objaśnienia zob. tab. 1.

The second study period, the results of which are shown in Table 11, proved the most difficult period for the cows. Ten additional animals each were introduced into groups I and II, thus considerably increasing the density of the studied groups. There was a decrease in milk yield, which ranged from $24.63 \mathrm{~kg}$ for group I to $27.65 \mathrm{~kg}$ for group II. In group III, where the unit area due to removal of cows from groups I and II increased, the production level was found to be much higher $(29.45 \mathrm{~kg})$. Highly significant differences between the groups are shown in the table. In turn, the findings of Wang et al. (2016) show that when stocking density was decreased by $18 \%$, milk yield increased, but higher milk production was also observed when stocking density increased by $29 \%$.

Table 11. Characteristics of daily milk yield in cows from different study groups during the experimental period II

Tabela 11. Charakterystyka dobowej wydajności mlecznej krów w poszczególnych grupach badawczych w okresie doświadczalnym II

\begin{tabular}{|c|c|c|c|c|c|c|c|c|c|}
\hline $\begin{array}{c}\text { Study } \\
\text { period } \\
\text { Grupa } \\
\text { badawcza }\end{array}$ & $\begin{array}{c}\text { Milk yield } \\
\text { Wydajność } \\
\text { mleczna } \\
{[\mathrm{kg}]} \\
\bar{x} / \mathrm{sd}\end{array}$ & $\begin{array}{c}\text { Fat } \\
\text { content } \\
\text { Tłuszcz } \\
{[\%]} \\
\bar{x} / \text { sd }\end{array}$ & $\begin{array}{c}\text { Protein } \\
\text { content } \\
\text { Białko } \\
{[\%]} \\
\bar{x} / \text { sd }\end{array}$ & $\begin{array}{c}\text { Fat/protein } \\
\text { ratio } \\
\text { Tłuszcz/ } \\
\text { /białko } \\
\bar{x} / \text { sd }\end{array}$ & $\begin{array}{c}\text { Lactose } \\
\text { content } \\
\text { Laktoza } \\
{[\%]} \\
\bar{x} / \mathrm{sd}\end{array}$ & $\begin{array}{c}\text { Conductivity } \\
\text { of milk } \\
\text { Przewodność } \\
\text { mleka } \\
\text { [mmho] } \\
\bar{x} / \mathrm{sd}\end{array}$ & $\begin{array}{c}\text { Milking } \\
\text { duration } \\
\text { Czas doju } \\
\text { [min] } \\
\bar{x} / \mathrm{sd}\end{array}$ & $\begin{array}{l}\text { FCM } \\
{[\mathrm{kg}]} \\
\bar{x} / \mathrm{sd}\end{array}$ & $\begin{array}{l}\text { ECM } \\
{[\mathrm{kg}]} \\
\bar{x} / \mathrm{sd}\end{array}$ \\
\hline I & $24.63^{\mathrm{AB}}$ & $3.53^{\mathrm{Aa}}$ & $3.59^{\mathrm{A}}$ & $0.98^{\mathrm{A}}$ & $4.29^{A}$ & $10.53^{\mathrm{AB}}$ & $6.65^{\mathrm{A}}$ & $22.39^{A}$ & $29.59^{A B}$ \\
\hline$n=312$ & 9.92 & 0.71 & 0.33 & 0.22 & 0.35 & 1.08 & 1.65 & 8.16 & 11.45 \\
\hline II & $27.65^{\mathrm{A}}$ & $3.42^{\mathrm{Ba}}$ & $3.69^{A B}$ & $0.93^{\mathrm{A}}$ & $4.38^{\mathrm{AB}}$ & $9.75^{\mathrm{A}}$ & $6.73^{\mathrm{B}}$ & $25.04^{\mathrm{A}}$ & $34.07^{A}$ \\
\hline$n=362$ & 9.39 & 0.60 & 0.34 & 0.18 & 0.32 & 0.81 & 1.62 & 7.46 & 10.48 \\
\hline III & $29.45^{B}$ & $3.71^{\mathrm{AB}}$ & $3.59^{B}$ & $1.04^{\mathrm{A}}$ & $4.41^{\mathrm{B}}$ & $9.84^{\mathrm{B}}$ & $7.82^{\mathrm{AB}}$ & $28.78^{\mathrm{A}}$ & $34.99^{B}$ \\
\hline$n=143$ & 9.37 & 0.73 & 0.36 & 0.23 & 0.34 & 1.26 & 1.82 & 8.54 & 11.38 \\
\hline
\end{tabular}

Explanations see Table 1 - Objaśnienia zob. tab. 1.

The presented results do not fully confirm this study. In group I, the decrease in milk yield was paralleled by a decrease in fat content in relation to group III, and also by shorter milking duration. Such a relationship between milk fat content and milk yield was reported by D'Hour et al. (1994). Milk lactose content slightly decreased. In group II with outdoor access, overstocking did not cause a large reduction in the milk yield of the studied cows, as was the case in group I. However, there were decreases in milk fat content, lactose content and electrical conductivity. Analysis showed that protein percentage reached a previously unrecorded level, from $3.59 \%$ for group I to $3.69 \%$ for group II. As a result, ECM for group II 
(34.07 kg) was not much different from that for group III (34.99 kg), despite the much higher content of fat $(3.71 \mathrm{~kg})$. The lack of differences is also due to the fact that both groups had outdoor access. Detailed statistical analysis is shown in the table.

It is concluded from the study that the housing conditions of dairy cattle have a direct influence not only on the production level, but also on the quality of the milk obtained. Because both short-term and frequent changes of production groups by the cows contribute directly to the decreases in daily milk yield, it is necessary to monitor the welfare of individual production groups.

\section{CONCLUSIONS}

1. Housing system and animal stocking density in the section significantly affect not only the milk production level, but also the milk somatic cell count. Cows without outdoor access had lower production with better quality parameters of the milk.

2. Age of cows is a factor that causes large differences in milk production and milk production parameters. The highest production potential was observed in the second lactation, and the highest SCC in the sixth lactation.

3. Cows kept without outdoor access with a space allowance of $3.8 \mathrm{~m}^{2} /$ head in relation to cows with outdoor access and a floor space of $7.74 \mathrm{~m}^{2} /$ head were characterized by much lower milk production (by $2 \mathrm{~kg}$ ). Milk fat content decreased with a slight increase in protein.

4. The short-term change in housing conditions by increasing the density from 3.8 to 3.16 $\mathrm{m}^{2} /$ cow without outdoor access caused small losses in the production of milk, fat, protein and lactose. A further increase in stocking density up to $2.71 \mathrm{~m}^{2} /$ head caused a reduction in milk production by $8.9 \mathrm{~kg}$.

5. Cows with permanent access to the outdoors, subjected to a short-term increase in stocking density from 7.74 to $6.45 \mathrm{~m}^{2} /$ head did not decrease their daily milk production, but there was a slight decrease in the content of ingredients such as fat and protein. Increasing the density to $5.35 \mathrm{~m}^{2} /$ head caused milk production to decrease by $7.46 \mathrm{~kg}$, but the content of basic milk components increased.

6. Despite the twice change in space allowance (increase from 6.24 to $17.6 \mathrm{~m}^{2} / \mathrm{head}$ ), the group of cows was characterized by markedly lower milk production (by $6 \mathrm{~kg}$ ) compared to the period when the group had stable space allowance and no changes were made.

\section{REFERENCES}

Abramowicz P., Brzozowski P., Gołebiewski M. 2014. Praktyczne aspekty społecznych zachowań bydła [Practical aspects of the social behavior of cattle]. Med. Weter. 70, 02, 90-93. [in Polish]

Berry D.P., Buckley F., Dillon P., Evans R.D., Rath M., Veerkamp R.F. 2003. Genetic relationships among body condition score, body weight, milk yield, and fertility in dairy cows. J. Dairy Sci. 86, 2193-2204.

Czerniawska-Piątkowska E., Szewczuk M., Snopkowska M. 2008. Porównanie użytkowości mlecznej krów rasy Polskiej Holsztyńko-Fryzyjskiej w różnych systemach utrzymania [Comparison of milk performance of polish holstein-friesian cows depending on the management system]. Zesz. Nauk. Uniw. Przyr. Wroc. 566, 25-34. [in Polish]

D'Hour P., Hauwuy A., Coulon J. B., Garel J. P. Garel. 1994. Walking and dairy cattle performance. Ann. Zootech. 43, 369-378. 
De Vries A., Dechassa H., Hogeveen H. 2016. Economic evaluation of stall stocking density of lactating dairy cows. J. Dairy Sci. 99, 3848-3857.

Edwards P.J., Jago J.G., Lopez-Villalobos N. 2014. Analysis of milking characteristics in New Zealand dairy cows. J. Dairy Sci. 97, 259-269.

Falk A.C., Weary D.M., Winckler C., Keyserlingk M.A.G. von. 2012. Preference for pasture versus freestall housing by dairy cattle when stall availability indoors is reduced. J. Dairy Sci. 95, 6409-6415.

Gnyp J., Kowalski P., Tietze M. 2006. Wydajność mleka krów, jego skład i jakość cytologiczna w zależności od niektórych czynników środowiskowych [Efficiency of the cow milk, its composition and cytological quality in relations to some environmental factors]. Ann. UMCS Sectio EE 24(3), 17-26. [in Polish]

Guliński P., Salamończyk E., Giersz B. 2007. Wpływ buhaja na liczbę komórek somatycznych w mleku krów czarno-białych [Effect of bull on the milk somatic cell count of Black and White cows]. Rocz. Nauk. Zoot. 34, 33-44. [in Polish]

Hunc D., Bryl M., Tietze M. 2006. Wpływ zapaleń podklinicznych wymion u krów na jakość i ilość mleka [Influence of subclinical udders on cows on quality and quantity of milk]. Kom. Nauk. PTZ (LXXI Zjazd Polskiego Towarzystwa Zootechnicznego, Bydgoszcz, 18-20.09.2006) 1, 14. [in Polish]

Krawczel P.D., Klaiber L.B., Butzler R.E., Klaiber L.M., Dann H.M., Mooney C.S., Grant R.J. 2012. Short-term increases in stocking density affect the lying and social behavior, but not the productivity, of lactating Holstein dairy cows. J. Dairy Sci. 95, 4298-4308.

Kraszewski J., Fijał J., Kuczara S. 2007. Wpływ warunków wolnostanowiskowego utrzymania krów na produkcyjność i jakość pozyskiwanego mleka [Effect of loose housing conditions of cows on productivity and quality of milk obtained]. Rocz. Nauk. Zoot. 34(1), 21-31. [in Polish]

Kuczyńska B., Budziński A., Kapusta A., Puppel K., Nałecz-Tarwcka T., Gołębiewski M., Wójcik A., Grodzki H. 2015. Relationships between production traits and the parity of Polish Holstein-Friesian cows. Ann. Wars. SGGW, Anim. Sci. 54(1), 51-57.

Loker S., Bastin C., Miglior F., Sewalem A., Scheaeffer L.R., Jamrozik J., Ali A., Osbornell V. 2012. Genetic and environmental relationships between body conditio score and milk production traits in Canadian Holsteins. J. Dairy Sci. 95, 410-419.

Medrano-Galarza C., Gibbons J., Wagner S., Passillé A.M. de, Rushen J. 2012. Behavioral changes in dairy cows with mastitis. J. Dairy. Sci. 95(12), 6994-7002.

Pilarska M. 2014. Wpływ pory roku i kolejnej laktacji na wydajność krów i parametry fizjologiczne mleka [Effect of season of the year and number of lactation on performance of cows and physico-chemical parametersof their milk]. Wiad. Zootech. 52(2), 3-12. [in Polish]

Radkowska I. 2012. Skład chemiczny oraz zawartość komórek somatycznych i mocznika w mleku krów w zależności od systemu utrzymania [Chemical composition, somatic cel count and urea content of cow milk depending on the housing system]. Rocz. Nauk. Zoot. 39(2), 295-305. [in Polish]

Reinholz-Trojan A. 2007. Znaczenie wiedzy o zachowaniu zwierząt w kontekście dobrostanu na przykładzie bydła domowego Bos taurus taurus. Zachowanie się zwierząt. Przegląd wybranych zagadnień z zakresu psychologii porównawczej. Warszawa, VizjaPress, 132-147. [in Polish]

Shuster D.E., Harmon R.J., Jackon J.A., Hemken R.W. 1991. Suppression of milk production during endotoxin-induced mastitis. J. Dairy Sci. 74(11), 3763-3774.

Wang F.X., Shao D.F., Li S.L., Wang Y.J., Azarfar A., Cao Z.J. 2016. Effects of stocking density on behavior, productivity, and comfort indices of lactating dairy cows. J. Dairy Sci. 99, 3709-3717.

Wójcik P., Rudziński J. 2014. Effectiveness of using activity tags in management of high producing dairy herd. Folia Pomer. Univ. Technol. Stetin., Agric. Aliment. Pisc. Zootech. 315(32), 59-66.

Abstract. The aim of the study was to determine the effect of varying housing conditions on production parameters of Polish Holstein-Friesian cows. The animals from the Experimental Station of the National Research Institute of Animal Production in Chorzelów were divided into three groups differing in housing conditions. The differentiating variables were access to 
outdoor areas and area per animal. Cows were also subjected to changes in stocking density and regrouping. The results showed that among cows without outdoor access, those with a space allowance of $3.8 \mathrm{~m}^{2} / \mathrm{cow}$ produced $2 \mathrm{~kg}$ less milk than those with a floor space of $7.74 \mathrm{~m}^{2} /$ cow. Increasing stocking density from 3.8 to $2.71 \mathrm{~m}^{2} /$ head reduced milk production by $8.9 \mathrm{~kg}$. In cows with outdoor access, decreasing floor space allowance from 7.74 to $5.35 \mathrm{~m}^{2} /$ head reduced milk production by $7.46 \mathrm{~kg}$. Two changes in the living area, including increased floor space (in another group) from 6.24 to $17.6 \mathrm{~m}^{2}$ also caused milk yield to decrease by $6 \mathrm{~kg}$. The decreases in milk yield increased the solids content per litre of milk. The study found that housing system and stocking density determine the level of milk production. Too frequent changes in stocking density, as well as regroupings have a negative effect on milk yield. 
